\title{
The representation of trans women in Brazilian magazine covers
}

\author{
As representações de mullheres trans em capas de revista brasileiras \\ Las representaciones de mujeres trans em portadas de revistas brasileñas
}

Received: 02/05/2021 | Reviewed: 02/11/2021 |Accept: 02/12/2021 | Published: 02/19/2021

Fabiano Eloy Atílio Batista

ORCID: https://orcid.org/0000-0001-7067-560X Universidade Federal de Viçosa, Brazil E-mail: fabiano.batista@ufv.br

Débora Pires Teixeira

ORCID: https://orcid.org/0000-0002-3143-8676 Universidade Federal Rural do rio de Janeiro, Brazil E-mail: deborapite@gmail.com

Glauber Soares Junior

ORCID: https://orcid.org/0000-0001-9902-9740 Universidade Federal de Viçosa, Brazil E-mail: glaubersoares196@hotmail.com

Isadora Franco Oliveira

ORCID: https://orcid.org/0000-0001-6403-358X

Universidade Federal de São João Del-Rei, Brazil

E-mail: isadorafrnco@gmail.com

Matheus Nicolau Dias

ORCID: https://orcid.org/0000-0002-1430-0958 Faculdade Unyleya, Brazil

E-mail: matheusnicolau2010@ hotmail.com

Ítalo José de Medeiros Dantas

ORCID: https://orcid.org/0000-0003-0710-6142

Universidade Federal Campina Grande, Brazil E-mail: italodantasdesign@hotmail.com

\begin{abstract}
This work refers to an investigation into the representations of trans women in magazine covers of the national editorial market during the decade of 2010. Methodologically, it is qualitative, descriptive, and bibliographic research. Data collection took place from documents (magazine covers) and the data were analyzed using the Image Analysis technique. As a result, in general terms, we can understand that fashion magazines, in a certain way, sell mass ideas and ways of dealing with the body based on socially imposed standards of beauty - thin, white, and aesthetically impeccable, whereas, the other magazines seek to emphasize plural bodies that are closer to real figures, based on producing cultural values that go beyond aesthetic issues. It is concluded, therefore, that the representations of this social parcel that is so marginalized and culturally stigmatized must be further investigated, to broaden discussions in the most varied contexts.
\end{abstract}

Keywords: Magazine; Social representation; Gender and sexuality; Diversity.

\section{Resumo}

Esse trabalho refere-se a uma investigação sobre as representações de mulheres trans em capas de revista do mercado editorial nacional durante a década de 2010. Metodologicamente, trata-se de uma pesquisa qualitativa, de caráter descritivo e bibliográfico. A coleta de dados se deu a partir de documentos (capas de revistas) e os dados foram analisados com a técnica de Análise da Imagem. Enquanto resultados, em linhas gerias, podemos compreender que as revistas de moda, em certo modo, vendem ideias massificadas e modos de lidar com o corpo pautados em padrões de beleza impostos socialmente - magros, brancos e esteticamente impecáveis, no passo que, as demais revistas, buscam enfatizar corpos plurais e mais próximos de figurais reais, pautados em produzir valores culturais que vão além de questões estéticas. Conclui-se, portanto, que há de se investigar ainda mais as representações dessa parcela social que é tão marginalizada e estigmatizada culturalmente, com a finalidade de ampliar as discussões nos mais variados contextos.

Palavras-chave: Revista; Representação social; Gênero e sexualidade; Diversidade.

\section{Resumen}

Este trabajo se refiere a una investigación sobre las representaciones de las mujeres trans en las portadas de revistas del mercado editorial nacional durante la década de 2010. Metodológicamente, se trata de una investigación cualitativa, descriptiva y bibliográfica. La recolección de datos se realizó a partir de documentos (portadas de revistas) 
y los datos se analizaron mediante la técnica de Análisis de Imágenes. Como resultado, en términos generales, podemos entender que las revistas de moda, de cierta manera, venden ideas masivas y formas de tratar el cuerpo basadas en estándares de belleza impuestos socialmente: delgados, blancos y estéticamente impecables, mientras que, revistas, buscan enfatizar cuerpos plurales más cercanos a figuras reales, basados en producir valores culturales que van más allá de lo estético. Se concluye, por tanto, que las representaciones de esta parcela social tan marginada y estigmatizada culturalmente deben ser investigadas más a fondo, con el propósito de ampliar las discusiones en los más variados contextos.

Palabras clave: Revista; Representación social; Género y sexualidad; Diversidad.

\section{Introduction}

This work deals with an investigation of the representation of trans women in the covers of national magazines as a mechanism to systematize and, to a certain extent, bring discussions that broaden the studies about gender and sexuality issues as well as the social representation of this social group.

Campos (2014, p. 2718) argues that women exist in the most varied colors, shapes, sizes, and body arrangements. There are as many ways to be a woman as there are women in the world. However, linked to biological determinism, the concept of woman has historically been linked to the body that presented the female genitalia.

Stepping away from biological determinism, Butler (2008, p. 48) understands that the body is not "a passive medium on which cultural meanings are inscribed or as the instrument through which an appropriative and interpretive will determines a cultural meaning for itself'.

In the author's point of view, the passive and pre-speech body has Christian and Cartesian precedents in which it was understood as an inert and meaningless matter, a profane void, the fallen condition. The body itself is a construction in which the function of the speech and the power relations determine which bodies can materialize and which bodies can be considered as important. Discourses inhabit the body, Butler says: "Bodies in fact carry discourses as part of their own lifeblood. And nobody can survive without, in some sense, being carried by discourse" (Meijer \& Prins, 1998, p. 282).

According to Butler (2000), societies build norms that regulate and materialize the sex of the subjects and 'these norms' need to be constantly repeated and reiterated for the materialization to be concrete. In the book Gender trouble: feminism and the subversion of identity (2008), Butler states that the shape of the body is the product of a heterosexual scheme (or, as before, a 'matrix') that effectively shapes that body (Salih, 2013).

In the book Bodies That Matter: On the Discursive Limits of Sex, based on studies on cell biology, Butler says that a reasonable percentage of ten percent of the population has chromosomal variations that do not exactly fit the sets of categories $\mathrm{XX}$-female and XY-male, a fact that leads her to suggest that the existing sex/gender binarisms are inadequate to describe and categorize undetermined bodies (Salih, 2013).

Starting from the idea that conceives the active heterosexuality in the materialization of bodies, Butler (2008) introduces the discussion of abjection by gender intelligibility, which compulsorily associates sex/gender/sexual desire. That is, to materialize and be recognized as a human in a heteronormative society, the body anatomically identified as a male must perform masculinity, feel desire and have sex with women, while the body anatomically identified as a female needs to perform femininity, feel desire and practice sex with men. Bodies that do not fit into the so-called "intelligible genders" are considered aberrations, illegitimate, socially excluded, have their lives threatened, and are called abject bodies.

Butler (apud Meijer \& Prins, 1998, p. 281) says that the concept of the abject body refers to "bodies whose lives are not considered to be 'lives' and whose materiality is understood not to 'matter"' because abjection as a discursive process gets a kind of differential materialization of the human. Butler clarifies that these are not unthinkable bodies, which cannot be experienced or understood, but bodies that live within the hegemonic discourse as figures that are absolutely unquestioned, indistinct, without the content of something that has not yet become real. 
Thus, the abject designates precisely those "inhospitable" and "uninhabitable" areas of social life, which are nevertheless densely populated by those who do not possess the status of a subject (Butler, 2008). The abjection process has the consequences of the violence or exclusion of these bodies. According to Butler (2018), those who do not live by gender binarism and, therefore, constitute precarious lives, are often denied the right to appear, to walk on the street without being a victim of violence, to participate in public spaces, that is, to live a livable life. At the same time, they are subjects who seek the right to appear and to exist through collective alliances.

Struggling for existence and for being represented, bodies considered as abject were generally made invisible by the media in general. As some theories emerge seeking to deconstruct the body materiality linked to sex/gender/sexual desire, as well as the increase in the social pressure through the theme of inclusion and diversity in the media, hitherto invisible bodies, such as the fat, old, disabled, transgender, among other bodies, are now represented in different media.

In this context, the objective of the article is to bring a counterpoint to the representation of trans women on the covers of fashion magazines and other diverse segments, since reflecting on these representations is a way of questioning structures that are rooted in our society. Joly $(1994$, p. 1) says that we can think about the way the image communicates and transmits its messages, therefore, we cannot remain indifferent to one of the tools that dominate contemporary communication.

Woodward (2007) emphasizes that representation includes the practices of meanings and the symbolic systems through which significances are produced, positioning them as subjects. It is through the meanings produced by the representations that we give meaning to our experience and what we are. We can even suggest that these symbolic systems make possible what we are and what we can become. Representation, understood as a cultural process, establishes individual and collective identities, and the symbolic systems on which it is based provide possible answers to the questions: Who am I? What could I be? Who do I want to be? Discourses and systems of representation build the places from which individuals can position themselves and from which they can speak.

Therefore, observing these representations in the media, more specifically magazine covers, becomes essential to encourage reflection within a social field that has strong penetrating power, material and symbolic, in the daily lives of most of the subjects. Because these images, when linked to the social, historical, political, and cultural context strongly influence the formation and transformation of habits and ways of thinking. With their persuasive powers, they create and impose, directly or indirectly, ideals, values, beliefs, dreams, and expectations (Rockenbach, 2009).

\section{Methodology}

Methodologically, the referred study characterizes as qualitative and of the descriptive type. Where we sought to analyze and understand the multiple meanings present in the images presented on the covers of magazines and how they express visual information that, in a certain way, dialogues with everyday life, preaching, by purpose, values present in our culture (Lakatos and Marconi, 2003).

Data collection took place using the documentary method (Lakatos and Marconi, 2003), configuring this research as magazine covers, as it is understood that films, music, images, advertisements, magazines, and books are also pedagogical places that are, all the time, saying about us, either for what they show or for what they hide. They also say about our bodies and sometimes so subtly that we don't even realize how much we are captured and produced by what is said there (Goellner, 2010).

Thus, magazine covers belonging to the national publishing market were selected, with a time frame located in the 2010s, namely: Marie Claire (published in 2017), ELLE (published in the years 2011, 2016, and 2017), Vogue (published in 2017), Claudia (published in 2020), Época Negócios and TPM (both published in 2017).

The use of magazine covers as analytical material was, among several other factors, because it understood that these are "pedagogical devices of the media" (Fischer, 2002) present in different instances of society and need better examination. 
To this end, Fischer (2002) describes this device as a discursive apparatus (since it produces knowledge and discourses) and at the same time non-discursive (since it is a complex network of practices - producing, transmitting, and consuming TV, radio, magazines, newspapers - in a given society and a certain social and political scenario), from which there would be an incitement to the discourse about "yourself", to the permanent revelation of yourself; such practices are accompanied by production and dissemination of knowledge about the subjects themselves and their confessed and learned ways of being in the culture in which they live (Fischer, 2002).

The magazine covers were analyzed using the technique of "image analysis" proposed by Joly (1994), through which we sought to identify the aspects present in the representations of the images on the covers of magazines and how they dialogue with cultural values that, for purpose, influence the construction and representation of images.

\section{Conceptual Notions Between Mass Media, Fashion, and Representativeness}

Also called the 4th social power, the different multimedia channels are some of the greatest contemporary contributions to the transmission of messages, since it is in daily contact with all people around the world, presenting hyperconnectivity, enhanced by globalization, as well as a very high transmission speed (Castells, 1999; Santaella, 1996). In this universe, we focus on discussions in the mass media. The mass media not only transmit information, but they also do not just preach messages. They also disseminate ways of composing themselves, proposing lifestyles, ways of organizing daily life, of thinking, of fighting, of loving (Santos, 1994).

This idea introduces a daily discourse, which controls a huge part of the content conveyed by the mass media, especially considering its power of diffusion, as they are intrinsically related to the construction of the personas of a society, of how certain social figures will be previewed and pre-judged (Thompson, 2009). Akinro and Mbunyuza-Memani (2019, p. 308) explain that the media contributes to shaping the public's perceptions and attitudes since the media consistently and repetitively represents particular cultural trends. When it comes to the fashion field, we emphasize magazines as one of the main historical means of spreading thoughts, stereotypes, and subjugations, being in modern times aided by digital media.

Historically speaking, fashion information was primarily received in a society like Brazil through the leading fashion magazines that came from other countries and presented the different ways that people of high social class were dressing or experiencing their corresponding styles of life. Moeran (2013, p. 97) points out that magazines establish significant relationships between things that appear to be essentially independent; they give them a social life, creating an imaginary world about them. In this universe, magazines are one of the substantial means of mass communication. They played a fundamental role in the cultural construction of what gradually became a socially well-thought physical aesthetic thought - configuring this as essentially cisgender, straight, thin, white, and tall, seen as a perfect aesthetic that society indicates that it should be copied.

In the interim, with the arrival of the 20th century and globalization, pluralization and discussions about the need for much more diverse cultural thoughts started to gain more and more strength. Bonoto and Brignol (2020, p. 123) say that the debate on representativeness as an LGBT politician has advanced both in activism and academia. The number of LGBT characters is also growing, mainly in international productions. With that, it brought up a vast number of problems in the speeches broadcast primarily in fashion magazines, starting to demand a higher level of voice from people who were always marginalized, in these media, bringing positive representation. 


\section{Presentation and Analysis of Results}

Lea T., or, Leandra Medeiro Cerezo, is a Brazilian trans woman, model, and stylist, who gained notoriety after starring in the campaign of the European brand Givenchy, in 2010, and posing nude for the French Vogue magazine, in the same year. Lea T. was born in Belo Horizonte, Minas Gerais, on February 19, 1981. She is the daughter of former soccer player Toninho Cerezo with Rosa Medeiros. In Brazil, Lea T. starred on the cover of ELLE magazine twice, in 2011 and 2017, and Marie Claire magazine, in 2017, as we can see in Figures 1, 2, and 3.

Figure 1 - ELLE Brasil cover, December 2011 edition.

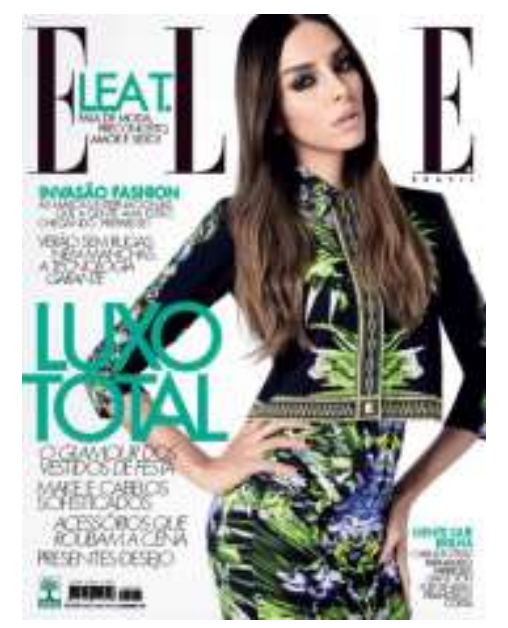

Source: http://www.metropolitanfashionista.com/2011/12/capa-de-revista-ELLE-brasil-dezembro.html (2020).

Figure 2 - ELLE Brasil cover, collector's edition, December 2017.

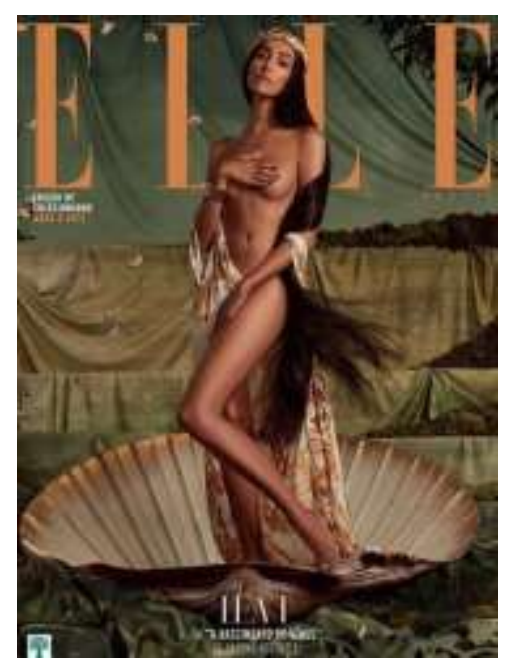

Source: Authors' collection. 
Figure 3 - Marie Claire covers, March 2017 edition.

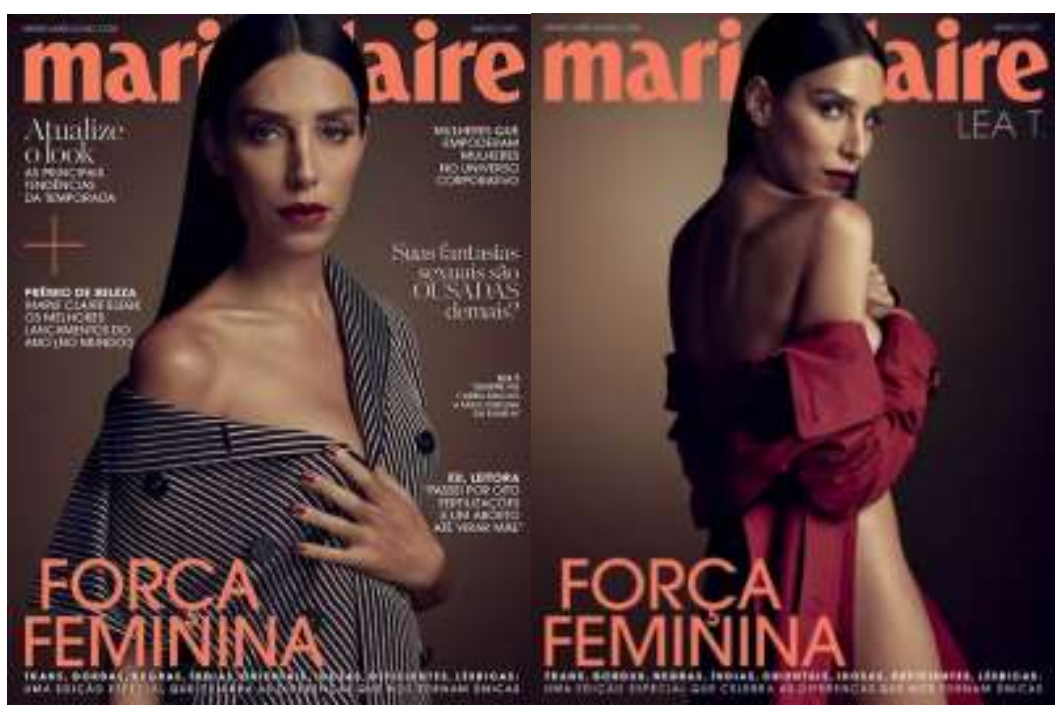

Source: https://www.marieclaire.globo.com/.

Another model to feature magazine covers was Valentina Sampaio, who is a trans woman, model, and actress. She was born in Aquiraz, Ceará, Brazil, on December 10, 1996. She was the first trans woman to be the cover of Vogue Brasil magazine. Besides, Valentina was the first trans model to star in Victoria's Secret campaign for their Pink line. In Brazil, the model was also on the covers of Vogue magazine and the cover of ELLE magazine, in 2016 and 2017 as we can see in the images below.

Figure 4 - ELLE Brasil cover, November 2016 edition.

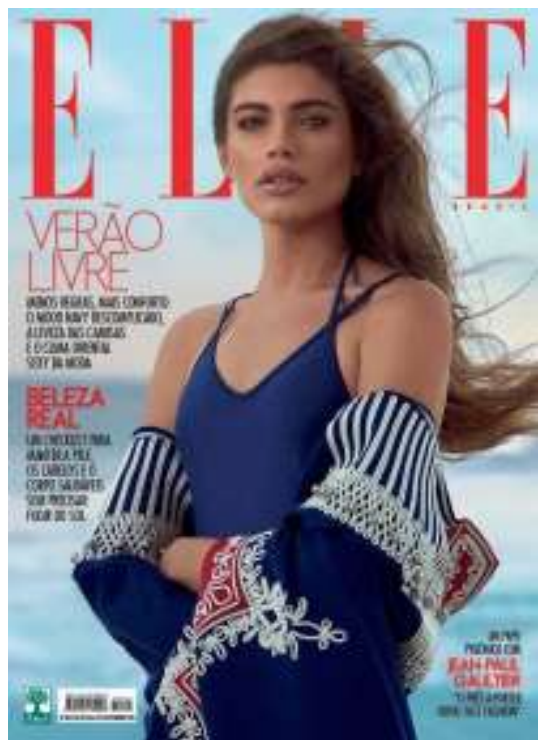

Source: https://veja.abril.com.br/blog/veja-gente/quero-ser-reconhecida-pela-mulher-que-sou-diz-modelo-trans/. 
Figure 5 - Vogue Brasil covers, December 2017 edition.

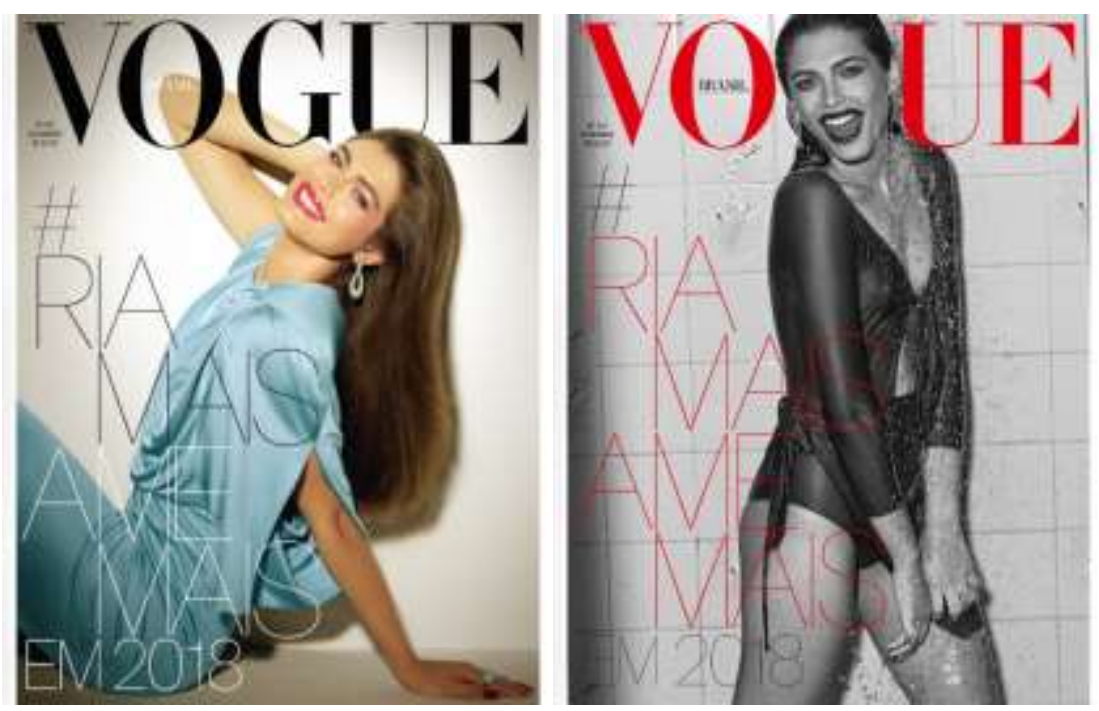

Source: https://vogue.globo.com/moda/moda-news/noticia/2017/12/valentina-sampaio-em-dose-dupla-na-vogue-brasil-de-dezembro.html.

Liniker de Barros Ferreira Campos, or simply Liniker, is a black and trans woman, born in Araraquara, São Paulo, in 1995. The Brazilian singer and songwriter participated as a member of the band Liniker e os Caramelows, but currently performs alone. She sings mostly soul and black music. The singer was on the cover of Claudia magazine, a special edition of March (month dedicated to women). The publication's slogan contains the following sentence: "Women who impact our tomorrow", as we can see in the image below.

Figure 6 - Claudia cover, March 2020 edition.

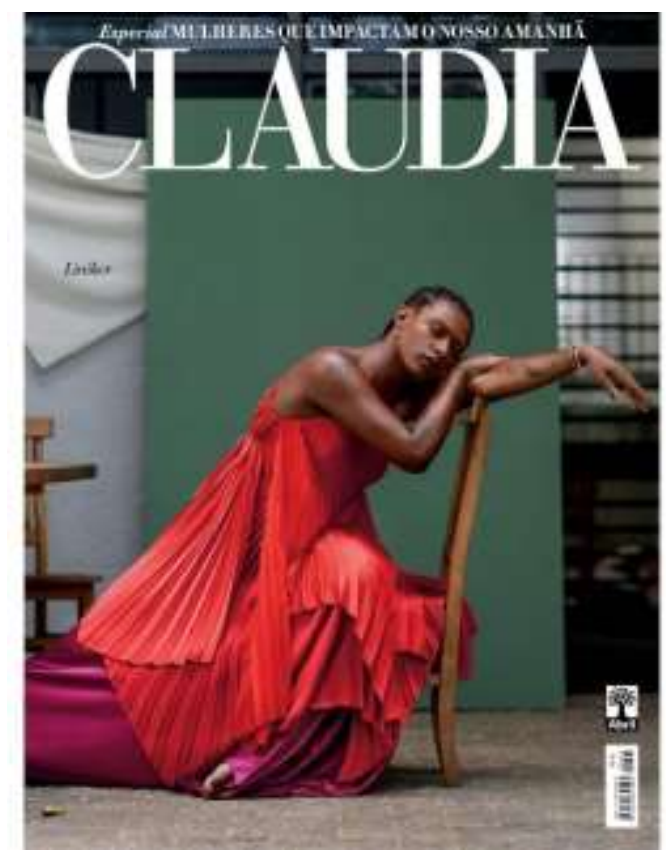

Source: Instagram @linikeroficial

Another cover identified by the research was that of Márcia Rocha. Businesswoman, lawyer, and first trans woman to act in Brazilian law using her social name (a name that differs from birth registration), granted by OAB (Order of Attorneys of 
Brazil - the Brazilian Bar Association). According to an interview with the Hypeness ${ }^{l}$ website, Márcia Rocha says that this achievement is important, because in the lawyer's words: "People die every day because of prejudice alone. Therefore, the possibility of making people think about this subject and see us as human beings, capable of working and exercising a profession with seriousness, as is the law, I think is extremely important".

Márcia stars the cover of Época Negócios magazine, under the theme: "Shall we talk about diversity?". It is also noteworthy that Márcia is a human rights activist and creator of TransEmpregos, the largest database of CV's and job opportunities for transgender people in Brazil.

Figure 7 -Época Negócios cover, June 2017 edition.

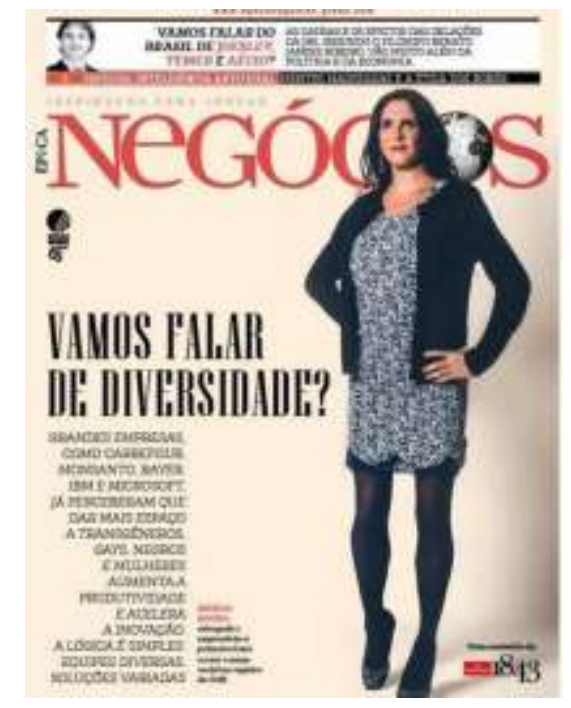

Source: https://epocanegocios.globo.com/Empresa/noticia/2017/06/como-sua-empresa-enxerga-diversidade.html .

Amara Moira, TPM magazine's protagonist for the November 2017 edition, holds a Ph.D. in literary studies from the State University of Campinas (UNICAMP) and defines herself as a "putafeminista" (feminist bitch, in a literal translation). She is a writer, columnist, and professor of literary studies and Portuguese. Amara starred the cover of the magazine whose central theme was "Is the future female?".

\footnotetext{
1 Available at: https://www.hypeness.com.br/2017/01/marcia-rocha-e-a-primeira-advogada-transexual-do-brasil-atuando-com-nome-social/. Retrieved in 13 December 2020.
} 
Figure 8 - TPM cover, November 2017 edition.

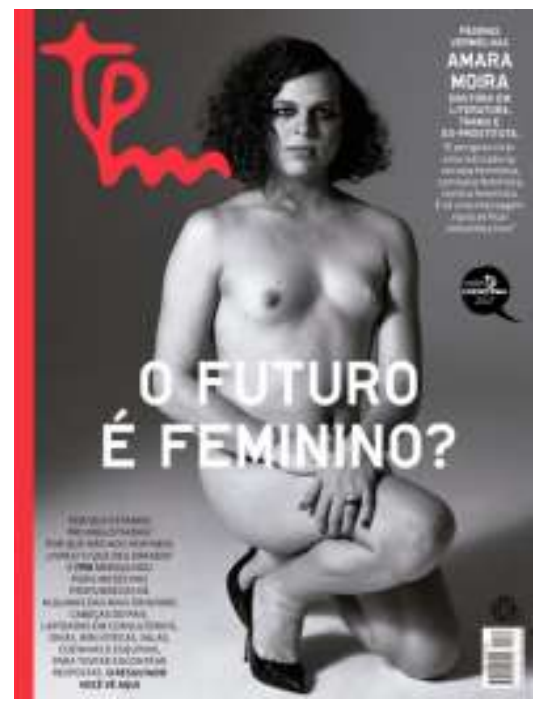

Source: https://revistatrip.uol.com.br/tpm/entrevista-com-amara-moira-doutora-em-literatura-ex-prostituta-travesti-e-bissexual

The analysis of the covers allows us to understand that the covers of magazines, in a certain way, make it possible to modify the view of trans women, taking them out of the condition of abject, marginal bodies. They are revolutionary and necessary in society. As Butler (2018) states, they are invisible bodies that are fighting for the right to be seen and to live. However, according to Heinzelman et al. (2012), even though this representation is beneficial, and, sometimes, considered as an advance, it is observed that the models present on the covers follow certain specific physical patterns and stereotypes of beauty.

On the covers of magazines related to fashion, like Elle and Vogue, in which the central figure is a professional model, there is the maintenance of a standard of beauty aimed at the female body: thin, tall, white, and with sharp features. This pattern is corroborated by Marie Claire, and despite not being a segmented magazine and belonging to the fashion editorial market, it is a magazine aimed at the modern woman and has in fashion one of its editorial pillars.

In this perspective, appearance is configured as a "value" of paramount importance for the recognition of subjects within the social context, since the ethics of beauty, and of fashion, can be defined as the reduction of all concrete values and the "use-values" of the body (energetic, gestural and sexual), to the only functional "exchange value" that, in its abstraction, sums up the idea of a glorious and accomplished body. From hygiene to makeup, going through tanning, sports, and multiple ways of freedom (Baudrillard, 1985).

According to Moreno (2008), magazine covers, as well as the media in general, convey images of women within an ideal; through framing mechanisms and logics, especially related to bodily issues, which favor certain models to the detriment of others. In this logic, the ideal image of a woman (trans or cisgender) is always dependent on looking young, vain, sensitive, delicate, in addition to being thin and sensual.

Goldenberg and Ramos (2002) emphasize that in the social environment, only one body is allowed and acceptable to be exported: sculpted bodies, without any imperfection, stains, excess of fat or signs of old age.

Thus, the covers of these magazines work as rules that are internalized and become the subjectivity of individuals - in this case, the recipients of the magazines (Furtado, 2008), directing the look towards certain body patterns and valuing them to the detriment of others. For the body is an agent of social differences and, being cultivated under the morality of good form, it appears as a mark indicating a certain superior virtue of the one who possesses it. A body covered with distinct signs which, even naked, exalts and makes visible the differences between social groups (Goldenberg \& Ramos, 2002). 
The censorship of plural bodies of trans women (fat, black, disabled, among others) by fashion magazines reaffirms a unique model of beauty and provokes in its audience a series of "stigmas" (Goffman, 1978), especially bodies trans, which are considered abject bodies (Meijer \& Prins, 1998).

However, when we leave the universe of fashion, we observe new possibilities of representations of these women, as shown on the covers of the magazines Claudia, Época Negócios, and TPM with plural women. From the visualities of these covers, we can see that there is a transmission of diverse, multiple bodies; they are black bodies, to some extent outside the imposed standards of cisnormativity, the curves are of real bodies, they are not extremely thin bodies. In other words, it is necessary to corroborate the statements, Bento (2018) claims that this multiplicity is important because, in the author's view, there is no "transsexual identity", but positions of identities organized through a complex network of identifications that take place through movements of denial and affirmation to the models made socially available to define what a "true" man/woman is.

Therefore, we can understand that there is neither a fixed nor essentialist trans identity, such as those conveyed on the covers of fashion magazines, but, above all, there are individual modes of performance of genres that will vary from subject to subjects, and all have their validity because there is no real transsexual, but transsexualities (Bento, 2004).

\section{Final Considerations}

Fashion magazines serve, still in contemporary times, as a mass tool for the transmission of thoughts, images, and stereotypes. For this reason, the cover of this vehicle is one of the main means of bringing out and highlighting a visual conformation that serves as a reference, as well as a reflection, for society itself. For a long time, certain groups of people were daily erased from these means of communication - the black community, fat people, and, as a focus in this research, trans people. Therefore, the objective of this work was to discuss the representations of trans people on magazine covers with a focus on the decade of 2010, appropriating the methods of image analysis, to build more meaningful and cohesive assertions. Through the development of this study, the intention was not to exhaust and end any discussion, but, above all, to intend reflections, punctual and necessary, on the representation and representativeness of trans women on magazine covers.

In this sense, we see that, although it has a positive transmission, the representations and representativeness of trans women in fashion magazine covers are guided by certain body patterns, which exclude, in a certain way, several other existences, such as fat bodies, black people, disabled, among others. Still, fashion magazines reinforce certain stereotypes of whiteness, thinness, and beauty.

When addressing the issue of Social Representations, it is important to highlight that it is about transposing reality, which always undergoes modifications, not being something static. In this sense, it is understood that there are different ways of communicating, therefore, as Theories of Social Representations, they are relevant for carrying out studies that analyze social phenomena in their different forms (Nogueira; Grillo, 2020).

Whereas, when viewing the placements in magazines were from the fashion field, we observed a multiplicity of bodies being disclosed. We can detect black bodies, non-cisnormative (that is, not guided by questions of the norm and passing as a necessary instance), among other possibilities that exist that encompass a more "real" and human reality of these subjects. Therefore, making it possible for other trans women to recognize themselves and feel represented.

Finally, it is reiterated that these covers work, even within certain limitations, as spaces and mechanisms that expand the ways of seeing/living/thinking/reflecting on the spaces that trans women occupy in society.

As future studies, it is suggested that research be developed that uses a quantitative approach, so that the number of magazines that have trans people on their covers can be mapped. 


\section{References}

Akinro, N., \& Mbunyuza-Memani, L. (2019). Black is not beautiful: Persistent messages and the globalization of "white" beauty in African women's magazines. Journal of International and Intercultural Communication, 12(4), 308-324.

Baudrillard, J. (1985). À sombra das maiorias silenciosas: o fim do social e o surgimento das massas: Brasiliense.

Bento, B. (2018). A reinvenção do corpo: sexualidade e gênero na experiência transexual. (3rd ed.): Devires.

Bento, B. (2004). Da transexualidade oficial às transexualidades. In: Sexualidade e saberes: convenções e fronteiras: Garamond, $143-172$.

Bonoto, C., \& Brignol, L. D. (2020). "É de confiar desconfiando": tensões e conflitos entre o ativismo LGBT e a mídia. Contracampo, [online] 39(1), 116130. https://periodicos.uff.br/contracampo/article/view/28512.

Butler, J. (2000). Corpos que pensam: sobre os limites discursivos do sexo. In: O corpo educado: Autêntica, $151-172$.

Butler, J. (2008). Gender trouble: feminism and the subversion of identity: Routledge.

Butler, J. (2018). Corpos em aliança e a política das ruas: notas para uma teoria performativa da assembleia: Civilização Brasileira.

Campos, D. M. A. R. (2014). Transgeneridade e feminilidade: uma etnografia acerca do que é ser mulher. $18^{\circ}$ REDOR, [online] 2718-2729. http://www.ufpb.br/evento/index.php/18redor/18redor/paper/view/2032.

Castells, M. (1999). A sociedade em rede. A era da informação: economia, sociedade e cultura: Paz e Terra.

Fischer, R. M. B. (2002). O dispositivo pedagógico da mídia: modos de educar na (e pela) TV. Educação e Pesquisa, 28(1), 151-162. https://doi.org/10.1590/S1517-97022002000100011.

Furtado, P. C. (2008). Moral, sociedade e mídia impressa: reflexões sobre os discursos do caderno "Turbine o seu prazer! O guia MH de sexo e relacionamento" da revista Men's Health. In: Anais do XIII Congresso de Ciências da Comunicação na Região Sudeste. [online] XIII Congresso de Ciências da Comunicação na Região Sudeste: Intercom/Universidade Presbiteriana Mackenzie. http://www.intercom.org.br/papers/regionais/sudeste2008/resumos/R90297-1.pdf

Goellner, S. V. (2010). A produção cultural do corpo. In: Corpo, Gênero e Sexualidade: Vozes.

Goffman, E. (1978). Estigma: notas sobre a manipulação da identidade deteriorada. (2nd ed): Zahar.

Goldenberg, M. and Ramos, M. S. (2002). A civilização das formas: O corpo como valor. In: Nu \& vestido: dez antropólogos revelam a cultura do corpo carioca: Record.

Heinzelman, F. L., von Muhlen, B. K., Schleiniger, C. dos S., Leite, M. D. P., \& Strey, M. N. (2012). Corpos em revista: a construção de padrões de beleza na Vogue Brasil. Psicologia em Revista, 18(3), 470-488. https://doi.org/10.5752/P.1678-9563.2012v18n3p470

Joly, M. (1994). Introdução à análise da imagem. Ed. 70.

Lakatos, E. M., \& Marconi, M. de A. (2003). Fundamentos de metodologia científica. (5th ed.): Atlas.

Meijer, I. C., \& Prins, B. (1998). How Bodies Come to Matter: An Interview with Judith Butler. Signs: Journal of Women in Culture and Society, 23(2), 275286.

Moeran, B. (2013). Lançando a moda: o discurso das revistas. Comunicação e Sociedade, 24, 95-119. https://doi.org/10.17231/comsoc.24(2013).1778

Moreno, R. (2008). A beleza impossível: mulher, mídia e consumo: Ágora.

Nogueira, K., \& Grillo, M. D. (2020). Theory of Social Representations: history, processes and approaches. Research, Society and Development, 9(9), e146996756. https://doi.org/10.33448/rsd-v9i9.6756

Pereira, A. S. et al. (2018). Metodologia da pesquisa científica. UFSM.

Rockenbach, M. R. P. (2009). A imagem feminina nas propagandas de cerveja. Revista Gestão, Científica de Administração e Sistema de Informação, 12(12).

Salih, S. (2013). Judith Butler e a teoria queer. Translated by G.L. Louro: Autêntica.

Santaella, L. (1996). Produção de linguagem e ideologia: Cortez.

Santos, J. L. (1994). O que é cultura. (14th ed.), Brasiliense.

Thompson, J. B. (2009). Mídia e modernidade: Vozes.

Woodward, K. (2007). Identidade e Diferença: Uma Introdução Teórica e Conceitual. In: Identidade e Diferença: A Perspectiva dos Estudos Culturais: Vozes. 